\title{
Çağdaş Eleştirel Kuramlar Bağlamında Laiklik Kavramına Bakış ve Türkiye'deki Evrimi
}

\author{
DOI: 10.26466/opus.792131
}

\author{
Nureddin Nebati * \\ * Dr, Bağımsız Araştırmacı \\ E-Posta: n.nebati1@gmail.com \\ ORCID: $\underline{0000-0003-3349-4986}$

\section{Öz}

Batı bağlamından ve belirli bir tarihsel dönemin ihtiyaçlarından doğan laiklik kavramı bütün toplumlar için mutlak bir medenileşme projesi olarak sunulmuştur. Bugün çağdaş sosyal bilim teorileri laiklik kavramının sınırlıliklarına işaret etmektedir. Laiklik teoride din ve vicdan hürriyetini de barındıran bir kavram olsa da pratikte bu şekilde vuku bulmamış ve pek çok toplumsal ve kültürel bağlamda dinin kamusal alandan dışlandığ̆ bir model uygulanmıştır. Tarihsel açıdan bakıldığında, Batı'da en dayatmacı ve dogmatik laiklik anlayışının uygulandı̆̆ üllke ise Fransa olmuştur. Fransa'nın laiklik yaklaşımı Türkiye modernleşmesi sürecinde birebir model alınmıştır. Türkiye'nin hususiyeti dikkate alınmadan, dine dair bütün öğeler kamusal alandan temizlenmiş, suni bir toplumsal ve siyasi alan tanzim edilmiştir. Bu toplumsal proje pek çok patoloji üretmiştir. Dindar kimliğin merkezi siyasete ulaşma hamleleri vesayetçi refleksler tarafindan düzenli olarak kesintiye uğratılmıştır. Demokrat Parti iktidarını sonlandıran 1960 darbesi, Anayasa Mahkemesi kararlarıyla kapatılan partiler, 28 Şubat süreci gibi süreçler toplumda ağır travmalar tetiklemiştir. Bu çalışmada önce laikliğin Batı'daki tarihsel ve kültürel gelişimi irdelenecek ve laiklik kavramına yönelik çağdaş eleştirel kuramsal bakışlara değinilecektir; ardından cumhuriyetin kuruluşundan bugüne dek Türkiye'nin laiklik anlayışının geçirdiği dönüşüm ve AK Parti iktidarn ile birlikte yaşanan yeni süreç tahlil edilecektir. AK Parti uzun bir mücadelenin ardından müesses nizamın vesayet araçlarından biri olarak kullanılan laiklik yaklaşımını, tarihsel ve sosyo-kültürel dayanaklarla uyumlu bir şekilde güncellemiş ve kamusal alanın ve ekonomik merkezin çoğulluklara ve İslami kimliğe açılmasımı sağlamıştır.

Anahtar Kelimeler: laiklik, Fransa, Türkiye, cumhuriyet, AK Parti, Charles Taylor, Talal Asad, Craig Calhoun 


\title{
Evolution and Overview of the Concept of Laïcité in Turkey in the Context of Contemporary Critical Theories
}

\begin{abstract}
The conception of laïcité is born out of a specific historical and cultural context in Western world, and has been presented as an absolutely essential component of modernization. Contemporary social science theories, however, point out the limitations of this conception. In theory, laïcité involves the freedom of conscience and religion, but in practice, this has not been the case, and in many social and cultural instances the religion has been excluded from the public sphere. From a historical perspective, France has seen the most patronising and dogmatic implementation of laïcité. And it is French conception of laïcité which was taken as a model for modernization of Turkey. Consequently, without the slightest regard for the defining characteristics of Turkey, all the religious elements were excluded from the public sphere, and thus an artificial political and social sphere was constructed. But this political and social construction has spawned serious pathologies, and, through hegemonic state mechanisms, hampered the political representation of religious identity in Turkey. As a result, there have been many traumatic events: The Democrat Party was overthrown in a military coup in 1960; many political parties were banned through the decrees of the Turkish Supreme Court; and the Turkish military leadership terminated the civil government through a military memorandum on 28 February 1997. This study will first examine the historical and cultural development of the conception of laïcité, and then present several contemporary critical theories discussing laïcite. The following part of the article will analyse both the evolution of laïcite from the beginning of the early Turkish Republican era, and the emergence of a new period during the AK Party government. After a long political struggle, the AK Party has modernized, in line with the historical and socio-cultural references in Turkey, the conception of laïcité, which has long been used as a hegemonic tool by the established state mechanisms. And this struggle paved the way for a public and economic sphere open to pluralities and the Islamic identity.
\end{abstract}

Keywords: laïcité, France, Turkey, republic, the AK Party, Charles Taylor, Talal Asad, Craig Calhoun 


\section{Giriş}

Dini kurumlar ile devlet kurumlarının ayrılması anlamına gelen laiklik kavramı her fert için düşünce ve vicdan hürriyetinin önemine ve kamusal alanda dinini ifade etme özgürlügüne de delalet etmektedir. Ne var ki teorik düzeyde kavrama yüklenen bu özellikler pratikte hayata geçirilememiş, laik düzenin tesisi dindar kimliğin kamusal alandan tamamen tasfiye edilmesiyle sonuçlanmıştır. Batı'nın siyasi ve kültürel bağlamında belirli bir tarihsel deneyimin ürünü olan laiklik kavramı uzun yüzyıllar boyunca bütün toplumlara uygulanabilecek yegâne medenileşme ve ilerleme modeli olarak lanse edilmiş, özellikle de Aydınlanma döneminin düşünsel iklimine damga vurmuştur. Ancak son 30-40 yılda yükselişe geçen ve modernleşmeci yaklaşımın patolojilerine dikkat çeken tarihsel sosyoloji, sosyal antropoloji ve siyasetbilimi çalışmaları ve analizleriyle birlikte, laiklik kavramı son derece problemli bir kategori olarak değerlendirilmiş, indirgemeci, arkaik, ayrımc1, kapsayıc1lığ 1 yetersiz bir modele işaret ettiğinin altı çizilmiştir. Charles Taylor, Talal Asad ve Craig Calhoun gibi pek çok düşünür laiklik yaklaşımının sınırlılıklarına işaret etmiş, "dini kamusal yaşamdan dışlamak" anlamında uygulanagelen laik/laikçi tarihsel deneyimleri demokratik olmamakla, aidiyeti ve kamusal alanda çoğulluğu sınırlamakla, dayatmacı bir bağlam üretmekle eleştirmiştir.

Toplumsal tarih ve siyasetbilimi literatürünün ortaya koyduğu üzere, laikliğin en militan ve baskıcı bir şekilde uygulandığı ülke Fransa'dır. Monarşi ile kilise iktidarı arasındaki güç mücadelesinin kullanıma soktuğu bir kavram olan laiklik, Ruhban sınıfının imtiyazlarının elinden alınmasını meşrulaştırıcı bir argüman olarak kullanılmıştır. Burjuva sınıfın artan egemenliği ile birlikte toplumsal ve siyasi hayattan dine dair bütün öğeleri cebren kazımaya dönüşen bu ayrımc laik rejim aşama aşama kurumsallaştırılmıştır. Fransa'da ortaya çıkan laiklik yaklaşımı münferit bir deneyim olarak nitelendirilemez. Nitekim Türk modernleşmesi sürecinde cumhuriyet elitleri Fransız laiklik modelini Türkiye toplumuna birebir uygulamışlardır.

Osmanlı'da Tanzimat ile başlayan modernleşme yolculuğu cumhuriyetin ilanıyla birlikte determinist bir üst-söylem halini almış, laiklik kavramı da cumhuriyetçi elitin topluma empoze ettiği modernleşmeci söylemler ve tezlerin temel dayanağı haline gelmiştir. 1924-25 döneminde başlayan laiklik reformları, giderek topyekûn ve yukardan aşağıya doğru gerçekleştirilen bir 
toplumsal dönüşümün anahtarı olarak konumlandırılmış, laiklik anayasal düzenin belirleyici ilkelerinden biri olarak kabul edilmiştir. Kurtuluş Savaşı sürecinde toplumsal birlik ve beraberliği konsolide etmek için kullanılan İslami söylem, tepeden inmeci bir rejimin inşası ile birlikte tamamen terk edilmiş, pozitivist ve toplumu kutuplaştııı bir laiklik yaklaşımı topluma dikte edilmiştir. Kendi toplumunun değerlerine ve kimliğine yönelik oryantalist bir bakışı içselleştiren cumhuriyet elitleri Ezan'ın Türkçeleştirilmesine dek varan kendini inkâr sürecinin mimarları olmuş ve bütün bu süreç pek çok travma ve patolojik sonuç üretmiştir.

Dönemin siyasi ve toplumsal konjonktürünün ürettiği zorunluluklar nedeniyle, cumhuriyetçi elitin çok partili sürece geçiş kararı alması ve Demokrat Parti'nin iktidarının ardından Türkiye yepyeni bir sürece girmiştir. Çok partili hayata geçişte, erken cumhuriyet döneminin ana paradigması olan laiklik siyasetinde birtakım dönüşümler yaşanmaya başlamış ve İslam'ın ve dindar kimliğin kamusal alandaki bütün izlerinin kazınarak, yer altına itildiği tek partili sürecin travmatik izlerini taşıyan yığınlar; kendi inanç, sembol ve değerlerini merkeze taşıyabilmek adına yeni dönemin sunduğu demokratik araçlara sarılmıştır. Nitekim topluma dayatılan laiklik yaklaşımı; derinlikli bir kültürü, inanç sistemi ve tarihi olan çok boyutlu bir toplumsal dokuda tutmamıştır. Gelgelelim kendi inanç, değer ve sistemleriyle uyumlu gördükleri partileri iktidarda görmek isteyen kitlelerin meşru hamleleri, kendini cumhuriyetin bekçisi gören merkezci, laik yapının daimi müdahaleleri, sürekli güncellenen bir vesayet sistemi ve onun kurumları aracıllğı ile kurduğu hegemonya yüzünden kesintiye uğratılmıştır.

80 sonrasının sivilleşme döneminde büyük anlatıların çöktügü; kültürel, etnik ve dinsel kimliklerin çoğullaştı̆̆ı, farklı yaşam biçimlerinin ve toplumsal tabakaların bir arada bulunduğu görece daha özgür bir dönem yaşanmıştır. Böyle bir atmosferde giderek daha görünür bir hale gelen İslami kimlik, 90'larda küresel çapta yükselişe geçen kimlik politikalarına içkin olan ifade özgürlüğü bağlamında siyasallaşma imkânı bulmuş ve kent yoksulları ile de irtibat kurarak önemli bir kitlesellik kazanmıştır. 1990'larda siyasal İslamcların merkeze yönelme hamleleri müesses nizamın temsilcileri tarafından zor araçları kullanılarak engellenmiştir. Tek parti döneminin düşünce ve uygulamalarını model alan 28 Şubat darbesi ile ordu doğrudan siyasete müdahalede bulunmuş, İslami kimliğe ilişkin bütün izleri kamusal alandan silmeye girişmiştir. 
Türk modernleşmesiyle bağlılaşık bir ilişki içinde ilerleyen laiklik yaklaşımının kısıtlayıcı çerçevesi Türkiye siyasal ve toplumsal hayatını kuşatarak daraltan bir çerçeve olarak 2000'li yıllara kadar varlık göstermiştir. Tek parti döneminin laiklik yaklaşımı gerek sunduğu deneyimler, gerek üretildiği bağlam ve tarihsellik itibarı ile son derece sınırlı, arkaik bir modeldir. Laiklik tasavvuru varabileceği en uç düşünsel noktaya ulaşmış ve entelektüel kapasitesini tüketmiştir. Nitekim bugün çağdaş sosyalbilim çalışmaları tarafından derinlemesine eleştiri ve sorgulamalara tabi tutulmaktadır. Türkiye'nin bu kısıtlayıcı, arkaik laiklik çerçevesini dönüştürerek, kamusal alanı merkezi ve siyaseti çoğulluklara, İslami kimliğe açması, ancak 28 Şubat sürecinin ürettiği basıncı lehine çevirerek iktidara gelen ve 2000'li yıllara damga vuran Adalet ve Kalkınma Partisi'nin iktidara gelmesiyle mümkün olabilmiştir. Uzun erimli ve pek çok siyasi riski göğüslemeyi gerektiren bu süreçte AK Parti merkezle girdiği çatışmaları millet iradesini arkasına alarak aşmış ve adım adım paradigma değişimine giden bu süreci inşa etmiştir.

\section{Batı'da Laiklik Tasavvurunun Gelişimi ve Günümüzdeki Eleştirel Durumu}

Laikliğin en güncel tanımlarından birini, günümüzde laiklik konusunda önemli çalışmalar yürüten Fransız sosyolog ve din tarihçisi Jean Baubérot ortaya koymuştur. Bu tanıma göre, laiklik üç ana unsurdan oluşan bir kavramdır: "devlet kurumları ile dini kurumların birbirinden ayrılması ve dini kurumların siyasi alana hiçbir müdahalesinin olmaması"; "her fert için düşünce, din ve vicdan özgürlüğünün temin edilmesi ve her ferdin kamusal düzenin sınırlamaları dahilinde dinini ifade etme ve değiştirme özgürlüğüne sahip olması"; "devletin hiçbir vatandaşına dini itikadı ya da din dışı görüşleri yüzünden ayrımcllık yapmayıp eşit davranması". Şüphesiz ki böylesine idealize edilmiş bir laiklik tasavvuru dünyanın hiçbir ülkesinde fiiliyata geçmiş değildir (Copson, 2019). Bu tasavvurun niçin gerçekleşemeyeceğini ve niçin demokratik ve çoğulcu bir toplum anlayışıyla tezat içinde olduğunu çağdaş sosyal bilimler alaninda Charles Taylor, Talal Asad ve Craig Calhoun gibi pek çok sosyolog ve düşünür derinlemesine irdelemiştir.

Baubérot'nun öne sürdüğüne benzer ideal laiklik kavramlaştırmaları öncelikle belli bir görüş çarpıklı̆̆ıyla maluldür. Bu tür görüşler, laikliğin 
Batı'nın belirli bir siyasi ve tarihsel bağlamının ürünü olduğunu ve dolay1sıyla evrensel ve mutlak bir nitelik taşımadığını göz ardı ederler. Batı'nın sekülerleşme ve laiklik modeli ne evrensel ne de normatif bir modeldir, sadece belli bir tarihsel deneyimdir (Gülalp, 2018, s. 67). Laiklik düşüncesinin ilk nüvesi, Vatikan'daki Katolik Papalık ile Avrupa'daki güçlü monarşiler arasındaki iktidar kavgasının akabinde, 1517'de Martin Luther'in başlattığı ve Protestanlık şemsiyesi altında toplanan Reformasyon hareketiyle atılmıştır. Luther'in gerek Katolik Kilise'ye getirdiği sert eleştiriler gerekse dünyevi iktidar ile ilahi iktidar alanları arasında yaptığı ayrımlar, laiklik tasavvurunun Batı siyaset düşüncesindeki ilk ciddi formülasyonu sayılabilir. Reformasyon'un ardından Avrupa' da yaşanan uzun kanlı din savaşları sonucunda monarşiler Kilise karşısında güç kazanmış ve dini kurumlar üzerinde mütehakkim bir konum elde etmiştir. Nihayetinde laiklik kavramının Avrupa'da ortaya çımasının başlıca sebebi, Avrupa'nın sürekli savaşlara gebe parçalı siyasi yapısı ve bu siyasi yapılanma içinde Katolik Kilise'nin başat bir siyasal erk olarak oynadığı roldür.

16. yüzyıldaki kanlı din savaşlarının akabinde, 17. yüzyılda laiklik düşüncesi Aydınlanma'ya giden yolda pek çok düşünür tarafından ele alınıp geliştirilmiştir. Bu düşünürlerin başında John Locke gelir. Locke, 1674 tarihli On The Difference Between Civil and Ecclesiastical Power [Sivil İktidar ve Ruhani Iktidar Arasındaki Fark Üzerine] adlı eserinde sivil toplum -Locke'un tanımıla devlet- ile dinsel cemaat -Locke'un tanımıyla Kilise- arasında bir farkın zuhur ettiğini söyler. Locke'a göre, Kilise'nin amacı öbür dünyada mutluluğun elde edilmesi iken, devletin amacı toplumsal huzurun ve refahın tesis edilmesidir. Devletin dünyevi alanın dışındaki hiçbir şeye müdahale etme hakkı yoktur (Locke, 1823). Locke'un izinden giden Montesquieu de dinin bir devletin kurucu unsuru addedilmemesi gerektiğini öne sürer. Keza Voltaire, David Hume, Jean-Jacques Rousseau ve Denis Diderot gibi diğer Aydınlanma dönemi düşünürleri de ayn fikrin izinden giderek devletin dinden azade bir teşekkül olması gerektiğini söyler. Hiç şüphesiz ki Aydınlanma döneminde öne sürülen bu tür görüşler ve teoriler, o dönemde Avrupa'da devletin kilise karşısında gitgide daha çok güçlenmesi ve zenginleşmesinin de doğrudan bir sonucudur. Devlet, bu dönemde sosyal refah ve eğitim gibi meselelerde kiliseden artık iyice bağımsızlaşmaya başlamış ve bunun sonucunda toplumsal düzenin muhafaza edilmesi ve meşruiyeti için kiliseye daha az muhtaç hale gelmiştir (Copson, 2019). 
Söz konusu süreçte laikliğin beşiği olarak bilinen Fransa'da olanlar dikkate değer ve manidardır. Her ne kadar Fransa pek çok Aydınlanma düşünürünün anavatanı olsa da 18. yüzyılda monarşinin halen otoriter bir siyasi iktidar vasfiyla, Katolik Kilise ile elbirliği içinde olduğu bir ülkedir. Literatürde Ancien Regime (Eski Rejim) diye geçen bu güçlü monarşi-kilise iktidarı 1789'da Fransız İhtilali ile devrilmiş ve akabinde bir kargaşa dönemi başlamıştır. Fransız İhtilali tek bir anda gerçekleşmiş bir devrim olmayıp, 1789 ile 1799 arasındaki on yıla yayılan bir sürece tekabül eden bir olaydır. Bu süreçte Kilise'nin tüm iktidarı elinden alınmış ve tüm malvarlığına el konmuştur. Oysa ihtilal öncesi Fransa'da en büyük toprak sahibi Kilise'dir. Ruhban sınıfının tüm resmi vasıfları elinden alınmış ve devlete bağlı memur haline getirilmiştir. 1799'da Napolyon Fransız İmparatoru olarak iktidarı eline almış olsa da, söz konusu on yılda Kilise ile devlet arasındaki ilişki büyük zarar görmüş ve kimi tarihçiler tarafından toplumun ve siyasetin cebren "Hıristiyanlıktan arındırılması" denen bir süreç yaşanmıştır (Hobsbawn, 2003, s. 267). Hiç şüphe yok ki 1789 'da ihtilal ilk patlak verdiğinde ihtilal liderlerinin, her ferdin din ve vicdan özgürlüğüne sahip olacağı yolundaki teminatı tamamen lafta kalmıştır. Akabinde Napolyon'un İmparator sıfatıyla tekrar monarşiyi kurmasıyla beraber, Katolik Kilise ile imzalanan bir anlaşma sonucu Kilise gücünü bir ölçüde tekrar kazanmış olsa da, 19. yüzyıl boyunca sekülerlik yanlıları ile ruhban iktidarı yanlıları arasında güç mücadelesi devam etmiş ve nihayetinde 1870 'lerden başlayarak sekülerlik yanlıları cumhuriyet rejimi içinde siyasi erki ele geçirmiştir. Ardından laiklik devletin kurucu unsuru olarak yerleşmeye başlamış ve kamusal alanda Katolik simgelerin kullanılmasına, Parlamento'nun açılışında duaların okunmasına, orduda papazların istihdam edilmesine yönelik yasaklar getirilmiştir. Okullardan din eğitimi kaldırılmıştır. Nihayetinde Fransa'da günümüzde de yürürlükte olan 1905 tarihli yasayla beraber, Napolyon'un vaktiyle Kilise ile yaptığı anlaşma feshedilmiş ve din devlet teşekkülünden tamamen ayrılmıştır (Copson, 2019).

Fransızcada laïcité [laiklik] kavramı da işte bu mücadele sürecinde ortaya çıkmıştır. Bu terimin o dönemde taşıdığı esas anlam, Fransa'da yaşanan tarihsel deneyim doğrultusunda kilise ile devletin birbirinden ayrılmasıdır; yani sivil hayatı dini veçhelerinden tamamen arındırmak suretiyle bir cumhuriyet etiği tesis etmektir (Copson, 2019). Böylelikle, laik bir devlet olarak Fransa birtakım değerlere, örneğin bireyciliğin iyi bir şey olduğu ya da dinin 
kontrol altına alınması gereken olumsuz bir şey olduğu yolundaki düşüncelere, başka değerler karşısında üstünlük tanımaktadır. Keza laik devlet bireyi dinden uzak tutmaya kalkışmakta ve dolayısıyla da bireyi din ve vicdan özgürlüğünden mahrum bırakmaktadır. Bu makalenin ilerleyen bölümlerinde ele alacağımız gibi, Fransa' da ortaya çıkan bu laiklik tasavvurunu anlamak, başka toplumsal bağlamlarda söz konusu laiklik tasavvurunun nasıl tesis edilmeye çalışıldığını idrak etmek için çok mühimdir; zira Türkiye'de erken cumhuriyet döneminde topluma empoze edilmeye çalışılan laik yaklaşım Fransız laiklik modelidir.

\section{Geçmişten Günümüze Laikliğe Yöneltilen Eleştiriler}

Yukarıdaki tarihsel kesitten de anlaşılacağı gibi, laiklik başta Fransa olmak üzere Batı'nın siyasi bağlamında oluşmuş bir kavramdır ve bu kavrama dair Avrupa-merkezci genellemeci görüşlerin böyle çetrefil bir meseleyi nesnel bir bakış açısıyla ele alamayacağı açıktır. Nitekim günümüzde hâlâ hayat buluyor olsa da laikliğe dair Baubérot'nunkine benzer idealist görüşler son 30-40 yılda çağdaş sosyalbilimciler tarafından irdelenmiş ve fazlasıyla eleştirilmiştir. Bu haklı eleştirilerin başlıca dayanak noktası da gerek devletin bir dinsel kimlik benimseyip kendi kimliğini bunun üzerinde temellendirmesinin kaç1nılmazlığı, gerekse de devletin dinden azade kılındığı bir bağlamda dindar insanların zorunlu olarak ayrımclığa uğrayacağını ve dindar olmayan fertlerle eşit muameleyi göremeyeceğidir.

Aslında laiklik tasavvuruna yönelik sert eleştiriler Aydınlanma döneminde de dile getirilmiş olmakla beraber, büyük ölçüde o dönemin Zeitgeist' 1 [zamanın ruhu] sebebiyle seslerini yeterince duyuramamıştır. Bunların en ünlüsü, John Locke'un savunduğu laiklik anlayışına getirdiği eleştirilerle tanınan İngiliz düşünür ve ilahiyatçı Jonas Proast'tır (1640-1710). Proast, dinî meselelerin bu dünyada yaşadığımız hayat üzerinde doğrudan etkisinin bulunduğunu, bu yüzden de din ile devlet arasında düpedüz bir ayrım yapılamayacağını savunmuştur (Proast, 1690).

Günümüzdeki duruma bakıldığında, sosyalbilimlerde Batı'nın sekülerleşme/laikleşme, Aydınlanma ve modernlik üçlemesini sorgulayan, bunların mirası ve meşruiyetini eleştirel bir analize tabi tutan ve bunların gerçekten de iddia edildiği gibi evrensel olup olmadığını irdeleyen bir literatürün geliştiği görülür. Özellikle laikliğe yönelik eleştirel düşünce hattı günümüzde gitgide 
güçlenmektedir. Bu eleştirilerin temel argümanı, laikliğin münhasıran Avrupa'nın dinsel ve felsefî geleneğinden türediği, yüzyıllar süren dinsel çatışmalar ve savaşlar yüzünden gelişmiş bir olgu olduğudu (Copson, 2019). Ayrıca bu eleştiri hattı, din ile dünyevi arasındaki teorik ayrımın Aydınlanma Çağı'nın ürünü olduğunu, dolayısıyla da evrensel bir nitelik taşımasının imkânsız olduğunu vurgular. Nitekim "din ile iktidarı ayırmak Reform [Protestanlık] sonrası özgül tarihsel sürecin ürünü olan modern Batılı bir normdur" (Asad, 1993, s. 43).

Bugün sosyalbilimler ve siyasetbilimi alanında, laiklik kavramına yönelik en önemli eleştiriyi yapan isim ünlü Kanadalı felsefeci ve tarihçi Charles Taylor'dır. Taylor, başta A Secular Age (2011) adlı kitabı olmak üzere pek çok çalışmasında sekülerleşme ve laikliğin Batı'daki tarihsel ve siyasi gelişimini her yönüyle irdeler. Taylor'un bu konudaki ana argümanı, Batı'da Hıristiyanl1ğın gelişiminin özgül bir sonucu olarak, Batı insanının dünyayı içkin (immanent) ve aşkın (transcendent) diye kesin çizgilerle ayırdı̆̆ını, oysa böyle bir ayrımın Batı-dışı dünyanın hiçbir yerinde bu denli kesinlikte mevcut olmad1ğıdır. Bunun sonucu olarak da Batı-dışı dünyanın tarihi boyunca "seküler" ya da "laik" gibi kavramların Batı'daki gibi belirli bir anlamı hiç olmamıştır. Batı'daki bu içkin ve aşkın ayrımı ise zamanla mutasyona uğramış ve nihayetinde aşkınlık, dünyevî hayatı bozan bir unsur addedilip tasfiye edilmiştir (Taylor, 2011, s.33).

Ayrıca günümüzde laiklik yanlısı düşünürlerin sıklıkla dile getirdiği ve en ünlü ifadesini ünlü siyasetbilim teorisyeni John Rawls'un Political Liberalism (1993) adlı kitabında bulan, liberal demokrasilerin düzgünce işleyebilmesi için dinî hakikatlerin siyasi gündemden tasfiye edilmesi gerektiği, aksi takdirde kamusal alanda fuzuli tartışmaların yaşanabileceği yolundaki argümana Taylor karşı çıkar. Taylor'a göre, dinî değerlerin kamusal alandan tasfiye edilmesini şart koşan böyle bir "programatik laiklik" anlayışının hiçbir gerekçesi olamaz, zira böyle bir durumda dindar insanlar, dindar olmayan insanlar karşısında dezavantajlı konuma düşecektir ki bu da demokratik bir toplumda kabul edilemeyecek bir husustur (Copson, 2019).

Sekülerleşme ve laikliğe karşı yöneltilen en esaslı eleştirilerden biri de antropolog Talal Asad'ın dile getirdiği eleştiridir. Asad'a göre, Hıristiyanlık geçmişleri ve Aydınlanma mirasları sebebiyle Batılılar dini bir nevi kişisel inanışlar koleksiyonu görmeye başlamışlardır; oysa Batı-dışı toplumlar için din bambaşka bir anlam taşır: Bu toplumlar için din, öncelikle bir cemaat içinde 
ifade bulan ve toplumun fertlerinin kimliği ve aidiyetinin aslî bir unsurudur. Dolayısıyla, dinin, diğer yaşam alanlarından koparılıp sadece özel alanla s1nırlandırılması gerektiği yolundaki fikir, Asad'a göre, Batı düşünce ve tarihinin başka toplumlara empoze edilmesinden başka bir şey değildir (Asad, 2003, s.8-10).

Öte yandan Amerikalı sosyolog Craig Calhoun'a göre, demokratik bir toplumda dindar insanların kamusal alanda fikirlerini beyan ederken sözlerini laik addedilen bir söyleme tahvil etmeleri gerektiği yolundaki sav temelsizdir ve Batılı liberal demokrasilerdeki ciddi bir adaletsizlik ve hakkaniyetsizliğe delalet etmektedir. Calhoun'a göre, liberal demokratik söylem, dinin kamusal alana katabilecek bir şeyi olmadığını savunmakla bir açmaza düşmektedir. Dinî görüşler de kamusal alandaki tartışmalara eklemlenmelidir. Calhoun bu konuda, Jürgen Habermas'ın görüşlerindeki değişimi örnek verir: Habermas önceleri, örneğin ünlü eseri Kamusallığın Yapısal Dönüşümü'nde (2003) kamusal alanın inşasında dine hiçbir işlev tanımamışken, zamanla bu görüşün demokratik ve çoğulcu kamusal alanın inşasında önemli bir sorun teşkil ettiğini görmüş ve sonraki çalışmalarında kamusal alana dair teorisinde dine de yer açmıştır. Calhoun'a göre bu çok önemli bir husustur, zira dini kamusal hayatın tam anlamıla meşru bir unsuru olarak görmek, aslında maneviyatı, en rasyonel kamusal söylemin meşru ve gerekli bir unsuru olarak görmek anlamına gelir. Nihayetinde en kozmopolit kamusal yaşam bile etnik, ulusal ve dinsel unsurlardan azade bir olgu değil, bilakis bu unsurların birbirlerine eklemlendiği bir yapıdır (Calhoun, 2011, s.76-77).

\section{Türkiye'de Erken Cumhuriyet Döneminde Laiklik Tasavvurunun Gelişimi ve Açmazları}

Osmanlı İmparatorluğu'nda “Tanzimat'tan sonra başlayan gelişmeler, hukuk ve eğitim alanında din dışı unsurların da (şeriye mahkemelerinin yanı sıra nizamiye mahkemeleri, medreselerin yanı sıra dini mahiyet taşımayan okullar) benimsenmesini sağlamış" olsa da (Narlı, 1994, s.24), gerçek anlamiyla laiklik ilkesinin temelleri 1923'te Cumhuriyetin kurulmasıyla atılmıştır. 1924-25 dönemi ise laiklik reformlarının başlangıç zamanıdır (Bora, 2018, s.148). 1924'te hilafet kaldırılmış, Tevhid-i Tedrisat Kanunu çıkarılarak özerk dini eğitim faaliyeti men edilmiş, Şeriye ve Evkaf Vekaleti kaldırılarak dinî 
işler ve hizmetler Başbakanlığa bağlı Diyanet İşleri Başkanlığı'na devredilmiştir. 1925'te tekke, zaviye ve türbeler kapatılmış, şapka reformu yapılmıştır. Ardından 1926'da Batı yasalarından devşirilmiş bir laik medeni kanun çıkarılmış, 1928'de alfabe değiştirilerek Latin harfleri kabul edilmiştir. Ayrıca 1932'de ezanın Türkçeleştirilmesi gibi tuhaf girişimlerde de bulunulmuştur. Devlet yapısını topyekûn laikleştirmeye yönelik bu hamleler bir süre sonra anayasal düzeye de taşınmıştır. Önceleri 1924 anayasasında devletin dininin İslam olduğuna dair bir madde varken, 1928' de devletin dininin İslam olduğuna ilişkin bu madde anayasadan çıkarılmış, ardından 1937' de yapılan anayasa değişikliğiyle laiklik, yasanın lafzında da yerini alarak bir anayasa ilkesi haline getirilmiştir (Esen, 1968, s.110).

Erken Cumhuriyet Döneminde laikliğin tesis edilmesindeki en önemli husus, laikliğin bu dönemde toplumsal yapıya bir anda vazedilmemiş, birtakım stratejik dolayımlar üzerinden tedricen hayata geçirilmiş olmasıdır. Nitekim Atatürk, bu konuda önceleri İslamiyet'e gönderme yapan bir söylem geliştirmiş, örneğin 1920'de Anadolu halkından, İslamiyet tarafından birleştirilmiş etnik bir mozaik olarak söz etmiş, ve o yıl mecliste yaptığı bir konuşmada şunları söylemiştir: "Burada maksut olan ve Meclisi alinizi teşkil eden zevat yalnız Türk değildir, yalnız Çerkez değildir, yalnız Kürt değildir, yalnız Laz değildir. Fakat hepsinden mürekkep anasır-1 İslamiyedir, samimi bir mecmuadır" (Atatürk'ün Söylev ve Demeçleri, 1990, s.74). 1923'te verdiği bir nutukta ise "bilcümle kavanini kevniyeyi [doğa kanunlarını] yapan Cenab-1 Hak'tır" demiş, 1924'te de "Türk milleti daha dindar olmalıdır" diye belirtmiştir. Tepeden inmeci bir rejim inşasına ilişkin strateji dahilinde bu söylem tedricen değişmiştir. 1925'te Atatürk “İyi biliniz ki Türkiye Cumhuriyeti şeyhler, dervişler, müridler, mensuplar memleketi olamaz. En doğru ve en hakiki tarikat tarikat-1 medeniyedir. Medeniyetin emir ve talep ettiğini yapmak insan olmak için kafidir" (Bora, 2018, s.148) sözlerini sarf ettiğinde, artık pozitivist laiklik anlayışı kendini göstermeye başlamıştır.

Aslında bu laiklik anlayışının mahiyeti, cumhuriyeti kuran seçkinci kadroların ağzından doğrudan da dile getirilmiştir. Hakimiyet-i Milliye'nin 10. yıl nüshası, Cumhuriyet Türkiyesi'nde laikliğin Fransa'daki gibi "din ve dünya işleri arasında bir mütareke"den ibaret "pasif bir laiklik"olmadığını ikazında bulunur. Keza buna benzer bir zihniyet Emin Türk Eliçin'in Türk Inkilabı (1940) kitabında da karşımıza çıkar. Eliçin bu kitabında Türkiye'de bir yarı dinsizlik halinin bulunduğunu ve "hakiki Türk halkının ayık ve realist 
ruhunda mistik duyguların hiçbir zaman kök salmamış" olduğunu öne sürer (Bora, 2018, s.149). Kerameti kendinden menkul bu afaki ifadeler şüphesiz ki bu laiklik anlayışının ardındaki çarpık ve - Ayşe Kadıŏlu'nun tabiriyle-patolojik zihniyeti ortaya sermektedir (Kadığlu, 2010, s.489). Cumhuriyeti kuran kadrolar din başta olmak üzere, topluma esas niteliğini kazandıran her şeye nizam verme iddiasındadır. Tanıl Bora'nın işaret ettiği gibi, erken cumhuriyet laisizmi, kolay çözümlenemeyecek, duygusal karmaşalarla dolu bir deneyimdir (Bora, 2018, s.152). Kimi cumhuriyet eliti mensubunun yukarıda zikredilen düşünceleri göz önüne alındığında, bunun sırf duygusal bir karmaşadan ibaret olmadığını, büyük bir düşünsel ve mantıksal karmaşa da içerdiğini söyleyebiliriz. Nihayetinde erken dönemde Cumhuriyetçilik kendi ethos'unu dogmatik bir laikçiliğe indirgemiş ve bu da Türkiye'nin çok uzun bir süre yaşayacağı en büyük sorunların temelini hazırlamıştır.

Aslına bakılırsa bu düşünsel ve mantıksal karmaşanın altında yatan ana sebep, bu dayatmacı laiklik anlayışının temelinde çarpık bir ideoloji, Aydınlanmacı pozitivizm ideolojisi yatmasıdır. Arkoun'un belirttiği gibi, cumhuriyetin kurucu iradesinin gerekli eleştirel tutumu hiç takınmadan, öykünmeci bir biçimde kullandıkları soyut Aydınlanmacı prensipler, Batı'da bir ölçüde sonuca ulaşmalarını sağlayan tarihi bağlamdan koparılarak yeni bir sosyokültürel bağlama oturtulduklarında sakil kalmıştır. Kaldı ki Aydınlanma felsefesi, mevcut sosyal güçler bütününün içerdiği dinamiği ve farklı sosyo-ekonomik bağlamlardaki gelişimi göz önüne sermek konusunda gerekli entelektüel donanımı sağlamakta başlı başına yetersizdir. Böyle bir zaafla malul olan Aydınlanma düşüncesinin uzantısı olan pozitivist inanç ve pragmatik eylem eleştirel tutuma baskın çkarak cumhuriyet elitinin ana siyasi tavrını belirlemiştir (Arkoun, 1994, s.54). Bu bağlamda, Türk modernleşmesinin pozitivist bakış açısında tüm kötülüğün kaynağı din ile devletin ittifakı prensibi olmuştur ve sadece laik bir çözüm buna son verebilecektir (Arkoun, 1994, s.57).

Nitekim Erken Cumhuriyet Dönemindeki laikleşme ve modernleşme tarzı, cumhuriyet kurucu seçkinlerinin kendi Batı kültür modeli anlayışlarını dayatmalarının bir örneğidir. Bu seçkinci zihniyet, Fransız pozitivistlerine ait "düzen ve ilerleme" modelini benimsemiş ve bu yolla toplumsal denetim girişimlerini biçimlendirmiştir. Bu pozitivist Batı modelinin evrensel, akılcı, her zaman ve her yerde uygulanabilir olduğu savunulmuştur. Bu modele göre, toplumlar günün birinde Comte'un nihai pozitivist aşamasına varacaktır (Göle, 1998, s. 86). Oysa pozitivizm, doğa bilimlerinden beslenen bir düşünce 
akımıdır. Bu tasavvurda teknik akıl, toplumsal diyalektiğin yerini almıştır. M. Merleau-Ponty'nin (1973) dediği gibi, toplum doğa bilimlerinin yasalarına tabi bir olgu olarak görülünce, "onu doğayı yönetir gibi yönetmek kalır geriye; toplum, sadece mühendisler arasında tartışlabilen ve iş bitirme mantğını esas alan bir teknikle yönetilir" (s.95).

Günümüzden bakınca, bu pozitivist modelin ne kadar büyük bir ideolojik yanılsamanın ve tarihsellikten uzak çarpık bir anlayışın ürünü olduğu açıkça görülmektedir. Böylesi bir model, toplum mühendisliği ve tepeden inmeci cebrî uygulamalar yoluyla, toplumsal olan her veçheyi -dili, gündelik kültürel pratikleri ve özellikle de dini- regüle etmeye girişmiş ve bunun neticesinde toplumsal yapıda derin antagonizmalara ve açmazlara sebep olmuştur.

Ayrıca erken cumhuriyet laikleşmesini belirleyen pozitivist felsefenin Türkiye'de toplumsal özgürlüğün ve demokrasinin de sınırlarını belirlediği öne sürülebilir (Kadıŏlu, 1998a, s.42). Nitekim yukarıda da belirtildiği gibi, cumhuriyeti kuran yönetici kadroların pozitivizme dayalı modernleşmeci tasavvuru ile laiklik arasında düz bir bağlantı vardır. Hatta bu bağlantı o kadar çarpık kurulmuştur ki zamanla "ters nedensellik" denebilecek bir mahiyet kazanmıştır. Yani bu modernleşmeci modele göre, Batı'daki ortodoks sekülerleşme tezinin öne sürdüğ̈̈ "toplum modernleştikçe sekülerleşir" savının yerini, ters nedensellik yoluyla "toplum sekülerleştikçe, yani laik bir nitelik kazandıkça, modernleşir" savı almıştır. Dolayısıyla bu kurgulanmış ters nedensellik ilişkisi sonucu laiklik bir proje haline gelmiş ve üstelik modernleşmenin bir koşulu olarak görülmeye başlanmıştır (Kadığlu, 1998a, s. 44). Böyle bir akıl yürütmenin, mantık kurallarını hiçe saydığı ve rasyonel hiçbir zemininin bulunmadığı çok açıktır. Ancak, bu çarpık anlayış Türkiye' de demokrasinin ve çoğulcu bir kamusal alanın inşasının önündeki en büyük engel olarak uzun süre yaşamıştır. Zira cumhuriyet laikleşmesi dine dair tüm açılımları karşısına alarak kontrol etme, kendi amaçları doğrultusunda kullanma saiki içerir.

Dine dair bütün göstergelerin ve açılımların cebren kontrol altına alınması, aynı zamanda toplumsalı inşa eden başat unsuru, yani kolektif hafızayı ve temsiliyeti da bertaraf etme girişimidir. Arkoun'un çok isabetli bir biçimde tespit ettiği gibi, cumhuriyetin kuruluşunda gerçekleştirilen inkılaplar arac1lığıyla fesi şapkayla, geleneksel elbiseleri Avrupai elbiselerle, Hicri takvimi Gregoryen takvimle, Arap harflerini Latin harfleriyle değiştirmek, aslında 
"gerçeğe ve gerçeğin anlamlarının algılanmasına yön veren temel temsil unsurlarının (yazı, kıyafet, edebiyat gibi semiolojik sistemlerin) felsefi addedilen [dogmatik] bir değer yargisı uğruna yok edilmesi" anlamına gelmektedir (Arkoun, 1994, s. 58). Nitekim cumhuriyeti kuran yönetici kadroların yöntemi, büyük bir bütünleştirici güce sahip yeni bir sembolizm yaratmaktan çok uzaktır; zira "bu yöntem, dışarıdan ithal edilen, dolayısıyla yerel semiolojik sistemlerle ikame edilmesi ya da bu sistemlere eklemlenmesi mümkün olmayan -dış görünümü temel alan- bir dışsallığa ilişkin işaretler dayatmıştır" (Arkoun ,1994, s.59).

Kolektif temsiliyet ve hafızanın böyle ortadan kaldırılmaya çalışılması, aslında Türkiye'nin Osmanlı İmparatorluğu'ndan devraldığı kültürel mirası da tahrif etme sonucunu doğurmuş ve Ayşe Kadıŏlu'na göre, erken cumhuriyet dönemi laiklik anlayışının patolojileri dediği bir durumu ortaya çıkarmıştır. Osmanlı İmparatorluğu'nun sosyo-kültürel mantığı, çok çeşitli milli ve dini unsuru içermeye dayandığı halde, Cumhuriyetçi laiklik, dini kimliklerin özerkliğini tasfiye yolunu seçmiştir (Kadığlu, 2010, s.491). Cumhuriyet modernleşmesi hiçbir zaman başarıya ulaşması mümkün olmayan bir işe kalkışarak, Osmanlı mirasını silmeye girişmiş ve bunun için de laikliği her şeyi kendiyle başlatan miladî bir söylem haline getirmeye çalışmıştır (Bora, 2018, s.147).

\section{Çok Partili Dönem ve Ilımlı Laiklik}

II. Dünya Savaşı sonrası dönem geçmiş politikalarla belirgin bir şekilde kırılmayı ifade etmektedir. Adı faşizmle bütünleşen tepeden inme modernleştirici politikalar dünya ölçeğinde terk edilmeye başlanmış, liberal ekonomik politikalarla birlikte demokrasi yeni dönemin en temel söylemi olmuştur. Çok partili yaşama geçiş yükselen halk talebi ile değil, dünya konjonktürünün dayatması ve Türkiye' nin ABD’nin başını çektiği cepheye yaklaşma kaygisı nedeniyle yönetici elitin aldığı kararlar ekseninde hayata geçmiştir. 1940'ların ortalarında başlayan yeni dönemde dış dünyaya daha demokratik bir görünüm çizebilmek için yeni siyasal partilerin kurulması Cumhurbaşkanı İsmet İnönü tarafından teşvik edilmiştir (Koca, 2019, s.295). Bu koşullar altında Parti içinde dörtlü bir hizip oluşturan Celal Bayar, Adnan Menderes, Fuat Köprülü ve Refik Koraltan'a yeni bir parti kurmaları için yol gösterilmiştir. Yani bu dönemde rekabetçi demokrasiyi yaratabilecek gerçek altyapı 
ve demokratik koşullar aslında daha tam olarak olgunlaşmamıştır, geçiş bir şekilde merkezin vesayetinde gerçekleştirilmiştir.

Çok Partili döneme geçiş sürecinde CHP'nin, tek parti döneminde hayata geçirdiği dayatmacı laiklik politikalarını terk ederek ılımlı bir laikliğe geçişe kapı aralaması bağlamında önemli bir dönüşüm yaşanmıştır. Bunun bir sebebi Türkiye'nin bir parçası olmaya çalıştığı ABD hattının politikaları ile uyumlu olarak bu süreçte komünizmle mücadelede İslam'ın etkisinden faydalanma yaklaşımının ön plana çıkmasıdır. Truman Doktrini, Marshall Yardımları ve Amerika'nın komünizmle savaş politikası tarafından da şekillenen bu süreç Türkiye'nin liberal kanattaki varlığını perçinlemek için kullanılmıştır (Koca, 2019, s. 295). CHP'nin dayatmacı laiklik çizgisinin II. Dünya Savaşı sonrasını takiben bir ölçüde evrim geçirdiğini söylemek mümkündür. Belirli sınırlar içinde ve kontrollü olarak din eğitimine izin verilmesi, Milli Eğitim Bakanlığı'na bağlı İmam Hatip kurslarının açılması, hacca gitmek isteyenlere döviz sağlanması gibi kararlar bu dönüşümün göstergesidir. CHP'nin dayatmacı laiklik anlayışını bırakarak dini hayata hürmet gösteriyormuş gibi davranmasının altındaki bir sebep komünizm düşmanlığı ise diğer sebep de 1946 yılında 61 milletvekili ile meclise giren Demokrat Parti'nin varlı̆̆ıdır. DP Parti programinda "dini hürriyetlerin mukaddes bir hak" olduğunu belirtmiş ve bunun sonucunda muhalif kesimler tarafından desteklenen bir parti olmuştur. Öte yandan, Cumhurbaşkanı İsmet İnönü bir yandan DP'nin kuruluşu evresinde DP Genel Başkanı Celal Bayar'dan partinin dini kullanmayacağına dair söz almış, diğer yandan dine serbestlik tanıyarak DP'ye giden oyların yükselişini engellemeye çalışmıştır (Koca, 2019, s.296).

\section{Demokrat Parti İktidarı Yıllanı}

1950'de Demokrat Parti seçimleri kazanarak iktidara gelmiş ve Adnan Menderes başbakan olmuştur. 1950'ler boyunca girdiği bütün seçimleri DP kazanmış ve on yıl boyunca Menderes ülkenin başbakanı olarak kalmıştır. Ekonomik olarak $\mathrm{CHP}^{\prime}$ nin devletçi politikalarının aksine liberal bir hattın savunuculuğunu yapan DP, cumhuriyetin kurucu seçkinlerinin kullandığı söylemi bertaraf ederek, tek parti döneminde dini regüle etmeye yönelik dayatmacı laiklik politikalarına mesafe koymuş ve dine özgürlük sağlamak için pek çok politikayı hayata geçirmiştir. Dinsel özgürlüğe ilişkin bu reformist politikaların ilk adımı 1950'de parlamentodaki DP grubunun Arapça Ezan 
yasağını kaldırmasıdır. Partinin din konusundaki diğer reformist politikaları arasında bütün okullara seçmeli din dersini koyması, 19 İmam Hatip Okulu açması ve radyolarda dinî içerikli yayınlara yer verilmesi yer almaktadır (Kuru, 2009, s. 226). Demokrat Parti'nin dine yönelik özgürlükçü tavrı, partiye olan desteğin artmasında şüphesiz çok etkili olmuştur. Partiye verilen büyük destek içten içe büyüyen ama siyasi bağlam izin vermediği için ortaya çıkamayan büyük bir hoşnutsuzluğun dışavurumudur. Yok sayılan çoğunluk, katı jakoben seçkinlerin dayattığı pozitivist laikçi uygulamalardan hoşnutsuzluğunu sandığına yansıtmış ve DP'yi iktidara taşımaktan çekinmemiştir. Demokrat Parti'nin dine yaklaşımı CHP-DP çatışmasında partiye tartışılmaz bir üstünlük sağlamış, politikasını meşrulaştırmada önemli bir dayanak sunmuş ve kavrayıcı bir halk egemenliği düşüncesini hayata geçirmek konusunda en önemli nirengi noktalarından olmuştur.

Demokrat Parti'nin parti programına baktığımızda partinin din özgürlüğünü, temel insan hakları kapsamında ele aldığı gözlemlenmektedir: "Partimiz, lâyikliği, devletin din ile hiç bir ilgisi bulunmaması ve hiç bir din düşüncesinin kanunların tanzim ve tatbikinde müessir olmaması manasında anlar; din hürriyetini diğer hürriyetler gibi, insanlığın mukaddes haklarından tanır" (Demokrat Parti Parti Programı, 1946, s.4). Partinin karşı çıktı̆̆ şey laiklik kavramının kendisi değil, bir siyasi proje olarak laikliğin din karşıtlığı gibi algılanmasıdır. Menderes militarist laiklik yaklaşımına yönelik bir takım eleştiriler getirmekte ve CHP'nin dogmatik ve dayatmacı laiklik yaklaşımının toplumda yarattığı tahribatı şu şekilde özetlemektedir: "Biz o kadar feci bir vaziyetteyiz $\mathrm{ki}, 20$ milyon olan nüfusumuzun $\% 85$ 'i, hatta 90'ını teşkil eden Müslüman köylüler ölülerini yıkatıp gömdürecek adam bulamayacak hale gelmiştir" (TBMM Hükümet Programları, 2013, s.796). Ancak partinin dinsel özgürlüklere alan açma iddiası hiçbir zaman laikliği kategorik olarak reddetmek noktasına varmamıştır (Köktaş, 1997, s.194). Demokrat Parti her ne kadar muhafazakâr bir söyleme sahip olup, yığınların hassasiyetine denk düşen bir politika izlese de hiçbir zaman Türkiye'nin modernleşme ve Batı tarzı kapitalistleşme modelinin dışında bir siyasi dizge benimsememiştir. Aslına bakılacak olursa Demokrat Parti, CHP'nin kendisine yöneltebileceği potansiyel suçlamaları etkisiz kılmak için laiklik konusundaki hassasiyetini sıklıkla dile getirmiştir. Menderes ve Demokrat Parti dine alan açma konusundaki re- 
formları hayata geçirmeye çalışırken, bir yandan cumhuriyetin kurucu ilkelerinden biri olan laiklik yaklaşımıyla özsel bir çatışma içinde görünmemeye özellikle dikkat etmiştir.

1950 genel seçimlerinde Demokrat Parti'nin iktidara gelişi, laiklikle ilgili önemli söylemsel dönüşümlerin yaşandığı, kümülatif bir toplumsal ve siyasal değişim sürecine tekabül eden yeni bir dönemin başlangıcını oluşturur. Azak'ın da ifade ettiği gibi; çok partili dönemin görece demokratik ortamında, laiklik resmi ve anayasal bir prensip olmaya devam etmiş, ancak hükümetle özdeşleştirilen bir ideoloji olma özelliğini yitirmiştir. Dogmatik laikliği savunanlar devlet kurumları üzerindeki bütüncül hakimiyetlerini kaybetmişler, bu nedenle de seçilmiş iktidara karşı vesayet aygıtları üzerinden doğrudan bir hegemonya kurmanın mücadelesini vermişlerdir. İktidardaki hükümet bütün ılımlı yaklaşımına rağmen irtica faaliyetlerinin odağında olmakla suçlanmış, sivil toplum kuruluşları, muhalefet partileri ve basın irtica korkusunu yeniden üretmek amaciyla kullanılmıştır (Azak, 2019, s. 300). 1960 darbesine giden süreçte, askeri müdahaleyi meşrulaştırıc bir argüman olarak sıklıkla Demokrat Parti'nin dine olan tavrı sorgulanmıştır.

\section{0'lar ve Sonrasi}

1960 darbesi, 1950 öncesinin elitist sosyo-politik düzenini yeniden tesis etmeye yönelik bir girişimdir. Ordunun gölgesinde siyasal zeminin son derece kaygan olduğu, köyden kente göçün yoğunlaşarak, yeni toplumsal tabakaların, yaşam biçimlerinin varlık kazandığı ve artan toplumsal çeşitlilik karşısında topluma topyekûn nüfuz edecek bütüncül bir deneyim kurmanın giderek zorlaştı̆̆ı böyle bir atmosferde, millet iradesinin yegâne meşruiyet kaynağ 1 olarak görülmesinin önüne geçmek için çeşitli fren ve denetim mekanizmaları kurulmuştur. Yasama, yürütme ve yargıya bağımsızlık sağlanmış, bu yapıların birbirini denetlemesini öngören bir sistem üretilmiş ve böylece de yürütmenin ve iktidarın gücünün kırılması amaçlanmıştır. Kısa ömürlü kabineler ve buna bağlı istikrarsız dönemlere sebebiyet vermesi bahasına da olsa nispi temsil esası getirilmiş, hiçbir partinin tek başına iktidar olmasına izin vermeyen bu sistem inşa edilmiştir. Yürütmenin parçalanması ve kurulan fren ve denetim mekanizmaları ile topluma büyük ölçüde yön veren dinsel kodların siyasete dahil edilmesinin önüne geçilmeye çalışılmıştır. Edward Schneider'ın da altını çizdiği gibi, 1961 Anayasasının iki temel amacı vardır: 
Tek bir partinin sistemi tamamen domine ederek hakim olmasının önüne geçmek ve askeri kuvvetlerin bağımsızlı̆̆ının korunmasını sağlamak (Schneier, 2016, s. 149). Bu vesile ile dayatmacı laiklik tanımının mütemadiyen güncellenmesi ve siyasetin millete dair sembollerden düzenli olarak temizlenmesi sağlanmıştır.

1961 Anayasasiyla beraber iktidar, Anayasa Mahkemesi ve anayasal kurumlar aracilığıyla sınırlandırılmaya ve denetlenmeye çalışılmıştır. 1961 anayasasında Anayasa Mahkemesi, millet iradesinin yegâne meşruiyet kaynağı olarak görülmesinin önüne geçen bir mekanizmanın temel aktörlerinden biri olarak konumlandırılmıştır. Söz konusu anayasada siyasi partileri çeşitli yasaklar ve sinırlamalar getirerek kapatabilecek organ olarak Anayasa Mahkemesi yetkili kılınmıştır. 1961'den bu yana pek çok parti Anayasa Mahkemesi tarafından kapatılmıştır. Böylece Türk modernleşmesinin özünü oluşturan dayatmacı laiklik anlayışının kalesi 1960'dan itibaren 50 yıl boyunca hukuk olacaktır (Bora, 2018, s.152). Nitekim 1960 Darbesi sonunda kurulan Anayasa Mahkemesi laiklik tezinin düzenli olarak üretildiği temel mercii olmuştur (Bora, 2018, s.153). 1960'dan itibaren siyasal partilerin keyfî şekilde kapatılmasına dayalı bir rejim inşa edilerek, laiklik ilkesi bürokratik elitlerin, siyasi elitlerle giriştiği mücadelenin meşrulaştırıcı argümanı olarak kullanılmıştır.

\section{0’ler, Özal Dönemi ve Kontrollü Açılım}

12 Eylül 1980 askeri darbesinin ilan edilen amacı, 1970'lerin sonunda ortaya çıkan ve hem toplumsal yapıda kargaşaya hem de sosyo-ekonomik düzenin sistematik olarak aksamasına yol açan anarşizme ve terörizme son vermektir. Generaller darbenin gerekçelerinden birisi olarak İslami hareketlerin yükselişini, örneğin Milli Selamet Partisi'nin Konya Mitingini de işaret etmiştir (Kuru, 2009, s.228). Türkiye siyasetinin bir kez daha dışarıdan müdahale yoluyla dizayn edildiği bu askerî dönemde partiler lağvedilmiş, parti liderleri önce askerî üslerde gözetim altında tutulmuş, ardından yargılanmıştır. 1980 darbesi, tarihsel öncülü olan 1960'taki ilk müdahaleye benzer bir biçimde sistemin muhafızı rolünü üstlenen ordunun "siyasal sistemi tekrar rayına oturtmak" için müdahalede bulunduğu yolundaki argümanı güncellemiştir. 1980 darbesinin gerek ardında yatan mantık gerekse kurmaya çalıştığı üst anlatı, aşırı milliyetçilik, anti-komünizm ve ılımlı İslam'ın harmanlandığı, bu vesileyle İslam'ın aşırı ideolojiler karşısındaki kırıcı etkisinden faydalanıldığı bir 
çeşit melez modeldir. 1980 yılında Türk ordusu, Türk-İslam sentezini ayr1lıkçı etnik ve radikal solcu güçlerle savaşmak veya pasifleştirmek için ulusal tutkal olarak kullanmıştır. Bu yeni sosyo-ekonomik projeyi kontrollü ve kendi denetimi altında yürütmek için Milli Eğitim Bakanlığı, Diyanet İşleri Başkanlığı ve Devlet Planlama Teşkilatı'ndan yararlanmıştır (Yavuz, 2009, s.50).

1982 Anayasanın kabulünden sonra 6 Kasım 1983 seçimleri yapılmış ve bu seçimlerden Anavatan Partisi (ANAP) galip çıkmıştır. Böylece Türk siyasi hayatında yeniden bir sivilleşme süreci başlamıştır. ANAP Genel Başkanı Turgut Özal'ın 1983'ten 1989'a kadar başbakan ve 1993'e kadar cumhurbaşkanı olarak görev yaptığı süre boyunca demokrasi, sivilleşme, kamusal alanın farklı kimliklere açılması ve dayatmacı laikliğin esnemesi bağlamında önemli adımlar atılmıştır. Özal, Türkiye' yi küresel sisteme eklemleyerek ekonomik entegrasyonu sağlama bağlamında yaptığı hamlelerle bir yandan modernist bir çizginin savunucusu olmuş, diğer yandan da politikasında ve söylemlerinde önemli bir motif olarak dini kullanarak muhafazakâr bir yaklaşım ortaya koymuştur. Özal geleneksel merkezci, seküler ve elitist bürokratlardan farklı bir siyasi ilke ve program benimsemiş, geçmişte zıtlık içinde tanımlanagelen kavramları kendi kimliğinde birleştirmiştir. Bu yanıyla 80'lerin "katı olan her şeyin buharlaştı̆̆ı", keskin anlatıların ve büyük öğretilerin sorgulanarak melezliklere, farklı kimliklere, çoğulluklara alan açan sosyo-kültürel atmosferi ile uyumlu bir lider olmuştur. Nitekim Özal 1988'de Hacca giden ilk Türk başbakanıdır. Muhafazakâr siyasetçileri ve bürokratları teşvik ederek laik merkez ile çatışma yaşamış ve politikasında önemli bir motif olarak dini benimsemiştir. İmam Hatip okullarının yayılmasını desteklemiş, üniversitelerde baş örtüsü yasağını kaldırmak için mücadele vermiştir. Aynı zamanda Türk Ceza Kanunu'nun dini hislere ve fikirlere dayanan siyasi hareketleri yasaklayan maddelerinin de kaldırılmasına öncülük etmiştir; zira özellikle kanunun 163. Maddesine dayanarak geçmişte binlerce İslami hareket ve tarikat mensubunu tutuklanmıştır. Dolayısıyla Özal İslami hareketlerin yükselişini dolaylı olarak kolaylaştırmış, devletin ekonomik ve sosyo-kültürel yaşam üzerindeki tekelini zayıflatmış (Kuru, 2009, s.230) ve toplumsal düzen tahayyülünde dine önemli bir yer tanımıştır.

Tek partili dönemin ideolojik tasarımının belirlediği modernleşme projesi 1980'lere kadar gündelik hayatta dokunulmamış neredeyse hiçbir alan bırak- 
mamıştır. 1980 sonrasının neoliberal politikaları ve kültürel konjonktürü ekseninde ve Özal'ın liderliğinde, homojen laiklik yaklaşımdan ziyade hibrit yaşam biçimlerine ve melez kimliklerin varoluşuna alan açılmıştır (Yavuz, 2009, s.43). Özal önemli bir motif olarak dini kullanmak suretiyle çağdaş İslami kimliğin kamusal görünürlüğüne katkı sunarak reformist bir politika izlemiştir. 1980 sonrasının merkezin türdeşliğini yitirdiği, merkeze İslamcılar da dahil tepeden inmeci modernleşme yaklaşımına muhalif olan çok sayıda grubun dahil olduğu özgün bir atmosferde milli iradeyi bütün yönleriyle temsil eden bir siyasi iklimin tesis edilmesine katkıda bulunmuştur. (Kalaycioğlu, 2000, s.403).

\section{0'lar ve Güncellenen Vesayet}

Türk modernleşmesi kendi ideolojik tasarımı olan ulusal kimliği, İslam’la arasına koyduğu mesafe üzerinden tanımlamaya çalışmış (Yeğenoğlu, 2007, s.2) ve bunu gerçekleştirmek için İslam'ı hem marjinalize ederek sistem dışına itmeyi hem de kendi kurumları aracılığıyla kontrol etmeyi amaçlamıştır. Ancak bu durum Türk modernleşmeci zihniyetini beklemediği bir sonuçla yüzleşmek durumunda bırakmıştır. İslam'ın kamusal alana çıkışını engelleme ve onu denetleme çabaları, İslam'ın siyasallaşmasına giden süreci örmüştür (Kadığlu, 1998a, s.13). Türk modernleşmesinin toplumun içinde son derece baskın bir şekilde var olan kültürün temelini oluşturan İslam gibi bir temel kaynağı ve onun ışığında şekillenen tarihselliği bertaraf ederek, tarihi, siyaseti ve toplumu kendi ideolojik doğmaları etrafında şekillendirme çabaları tam tersi bir etkide bulunarak siyasal İslam'ın yükselişine olanak sağlamıştır. 1990'lar siyasal İslam'ın yükselişinin en görünür hale geldiği, onun ekonomik ve siyasal merkeze yönelerek ve kendine alan açma hamlelerinde belirgin bir başarıya ulaştığ 1 ve ardından çok sert bir müdahale ile karşılaşarak büyük bir mağduriyetle yüzleştiği özgün bir dönemi ifade etmektedir.

1990'lar modern ve geleneksel olanın tamamen ayrıştırarak sadece tek bir formun kabul edildiği toplumsal projesinin çöküşünün gözlemlendiği yıllardır. Kırdan kente göçün devasa boyutlarda arttığı, kentleşme hızı ve ekonomik büyümede patlamanın yaşandığı bu dönemde özellikle metropollerde farklı hayat biçimlerinin, aidiyetlerin, kültürlerin karşılaşma imkânı doğmuştur. Toplumsal çeşitlilik artık tek bir modern ve formun geçerliliğine indirgenemeyecek denli yoğun bir artış üretmiştir. Bunun sonucunda metropoller, 
ontolojik olarak birbiriyle çatışan iki dünya tasavvuru olan siyasal İslam ile modernleşmeci yaklaşım arasındaki toplumsal mücadelenin gözlemlendiği temel alanlar olmuştur (Kadığlu, 1998b, s.13). Bu toplumsal değişim, geçmişte daha ziyade taşra tarzı bir dindarlığın, Anadolu'nun ekonomik olarak sisteme dahil olmak isteyen eşrafının temsilciliğini üstlenen siyasal İslamcı bir yapı olan Milli Görüş hareketinin Refah Partisi çatısı altında toplumsallaşmasına ve büyük bir başarıya ulaşmasına vesile olmuştur. Refah Partisi dindarlar kadar, metropol yoksullarına, dezavantajllara, sistemin ezilenlerine ve merkezden tasfiye ederek periferiye mahkum ettiği kırılgan toplumsal kesimlere de umut vaad eden İslam temelli bir toplumsal proje sayesinde pek çok kesime ulaşmayı başarmış, bir kitle partisine dönüşmüştür. Nitekim 1994 yerel seçimlerinde İstanbul ve Ankara belediyelerini kazanan parti, 1995'te yapılan erken seçimlerde başarısını daha da ileri taşıyarak $\% 21.38$ oy oraniyla birinci parti olmuştur.

Milli Görüş hareketinin yükselişi ve tepeden inmeci modernizme getirdiği eleştiri; İslami değerleri vurgulayan söylemi ve alternatif ekonomik model anlayışı (adil düzen) sayesinde İslamcı entelijansiyaya önemli bir politik alan açmıştır (Bölükbaşı, 2012, s. 171). İslamcıların siyasi, entelektüel ve ekonomik alandaki atılımı; devlet yapısı içinde örgütlenen, kendini rejimin bekçisi olarak gören, tek parti iktidarı döneminin fanatik laiklik yaklaşımını temel ideolojik çerçeve olarak benimseyen, ordu ile simbiyotik bir ilişki içinde bulunan ve hem kendisine göbek bağı ile bağlı bir burjuvazi ile ekonomiyi domine eden hem de kültürel yapıyı topyekûn hegemonyası altına almak isteyen bürokratik elitleri deyim yerindeyse can evinden vurmuştur. 28 Şubat postmodern darbesi Anadolu burjuvazisinin ve giderek güçlenen İslamcı siyasal elitlerin önünü keserek adeta sistemi yeniden fabrika ayarlarına döndürme girişimidir.

28 Şubat postmodern darbesi ile ordu komutanları, hükümetin rejimin laik ve demokratik niteliklerine zarar verdiği gerekçesiyle politikaya doğrudan müdahalede bulunmuştur (Bölükbaşı, 2012, s. 175). Tarihsel öncülü olarak tek parti döneminin düşünce ve uygulamalarını model alan 28 Şubat darbesi aynı zamanda statükonun pozisyonuna dair bilgileri güncellemek anlamında önemli olmuştur. Bu darbe diğerlerinden farklıdır. Geçmişte yaşanan diğer darbelerde İslamcılarla birlikte farklı gruplar da hedef alınmış, örneğin 80 darbesinde İslamcilarla birlikte, solcular ve milliyetçiler de yara almıştır. Ancak 28 Şubat muhtırası “irtica tehdidi"ni meşrulaştırıcı bir argüman olarak 
kullanarak, İslam’a ait tüm izleri kamusal ve toplumsal yaşamdan silmeye çalışmıştır.

Dayatmacı laiklik tahayyülünün, toplumsal hayatı ve kamusal alanı yeniden hegemonya altına almaya çalıştığı 28 Şubat süreci topyekûn bir saldırı harekâtıyla beraber ilerlemiştir. MGK kararları doğrultusunda ve rejimin kurucu ideolojisi ekseninde işçi ve işveren örgütleri, medya, üniversiteler, basın gibi "silahsız kuvvetler" de harekete geçirilmiştir (Gökmen, 2002). Önce Refah Partisi ve ardından Fazilet Partisi olmak üzere "İslamcı parti" diye nitelenen partiler kapatılmıştır. Muhafazakâr ya da dindar olan vakıflar yoğun baskı altına alınmış, insan hakkı ihlalleri, toplu gözaltılar, başörtüsü yasağından dolayı toplu işten atılmalar olmuştur. İlahiyat Fakültesi mezunlarının öğretmenlik hakları ellerinden alınmış, kamu görevlileri ve sivil toplum örgütlerinin yöneticileri inançlarından ötürü fişlenmiştir. Dogmatik ve ideolojik modernite tasavvurunun var ettiği otoriteye, düzene, siyasete ve orduya tartışmasız, şartsız ve şekilsiz bir itaat istenmiştir (Tunahan, 2015, s. 34). Ancak, toplumsal dokunun çeşitliliğini ve toplumdan gelen talepleri baskılayarak, tarihsel olarak arkaik kalan, tek bir kimliği ve varoluşu referans alan bir modeli topluma empoze etmeye çalışmak, cebrî müdahaleler ile tersine çevirmeye çalışmak nafile bir çabadır. Dolayısıyla anakronik bir pozitivizmi temel alan bu toplumsal mühendislik girişimi kısa vadede başarılı olmuş gibi görünse de uzun vadede modernist-laik temelli toplumsal sözleşme modelinin çözülerek yeniden inşa edilmesine yol açan bir dizi gelişmeye yol açmıştır.

\section{0’li Yıllar ve Tarihsel Kökenlere Dönüş}

Uygarlık kavramı ve onun bağlılaşığı (correlation) olarak kabul edilen laiklik gibi kavramlar değer yargısından azade ya da tarafsız kavramlar değildir. Bilakis bunlar, "uygarca" tavır ve hareketleri benimseyenler ile barbarlığa mahkûm bütün ötekiler arasındaki güç ve iktidar ilişkilerini ifade eden kavramlardır. Nitekim Türk modernleşmesi sürecinde "medeni/uygar" sayılan ile "gayrimedeni/uygar olmayan" arasında bilfiil bir ayrım yapılmış ve "alafranga" yani Avrupa tarzı olan her şey uygun ve değerli kabul edilirken, "alaturka" yani Türk tarzı olan şeyler olumsuz bir nitelik kazanmış ve bir bakıma aşağı görülmüştür (Göle, 1998, s. 88). Türk modernleşmesinin kendi kültürüne dair öğeleri, kendi içinde geliştirdiği bir oryantalist mantıkla ötekileştir- 
mesi ve aşağıdan gelen toplumsal talebin sürekli olarak yukarıdan müdahalelerle baskılanması pek çok patolojik sonuç üretmiş, 28 Şubat süreci ile doruğa ulaşan sert bir çarpışmaya zemin hazırlamıştır. 2000'li yıllarda ise elitistlaik-modernist-dayatmacı toplum sözleşmesi modelinin millet ve siyasi elitlerin ittifakı ile, toplum lehine bir açılımla çözüldüğü yıllardır. 2002 sonrası Türkiye'yi dışlayıcı laikliğin sona ermesi ve devletin din ile barışık hale gelmesi anlamında "post-laik" olarak tanımlamak mümkündür (Bekaroğlu, 2015, s.104).

28 Şubat süreci politikaları ve bu süreçte gösterilen refleksler Milli Görüş Hareketi içinde önemli bir kırılma oluşturmuştur. "Yenilikçiler" ve "gelenekçiler" olarak görünürlük kazanan fikir ayrılıkları giderek keskinleşmiş ve bu fikir ayrılı̆̆ı yenilikçilerin hareketten koparak Adalet ve Kalkınma Partisi'ni kurmaları ile sonuçlanmıştır. Kendisini Siyasal İslam'ın referanslarıyla tanımlayan Milli Görüş Hareketi'nden farklı olarak, Adalet ve Kalkınma Partisi kendisini "muhafazakâr demokrat" olarak ifade etmektedir. O dönemde AK Parti Genel Başkanı Recep Tayyip Erdoğan partinin muhafazakâr demokrat siyasi çizgisinin dayandığı temel kriterleri şöyle tanımlamaktadır: "Geleneği dışlamayan bir modellik, yerelliği kabul eden bir evrensellik, manayı reddetmeyen bir rasyonellik, köktenci olmayan bir değişim" (Erdoğan, 2004). Muhafazakâr Demokrat kimlik tanımı içinde "din" ve "gelenek" vurgusu özellikle dikkat çekmekte, ancak modernizm ve rasyonellik de başka bir referans çizgisi olarak işaret edilmektedir. Bütün bu özelliklerin birbirini dışlamasının gerekli olmadığını, antagonist bir çatışma dili geliştirmekten ziyade tarihsel kökenlerden kopmadan da ilerlemenin mümkün olabileceği ve dahası bu kökenlere özgü bilgiden dünyayla bütünleşme yolculuğunda bir zenginlik ve güç olarak faydalanılabileceği vurgulanmıştır. AK Parti'nin Milli Görüş Hareketi'nde cisimleşen siyasal İslam'la arasına mesafe koyarak gerçekleştirdiği bu kimlik değişimi, 28 Şubat sürecinin yarattığı travmanın altında oluşumunu tamamlayarak siyasetteki daralmayı aşmak suretiyle kendine alan açma mücadelesi içinde olmasının sonucudur.

2002 seçimleri Türkiye tarihinde yepyeni bir sayfa açmıştır. Seçmenlerin parti tercihlerinde çok önemli kırılmalar olmuş, " 28 Şubat sonrasının 'giyabi hükümetini kuran partiler" seçmen desteklerini neredeyse tamamen yitirmişlerdir" (Bekaroğlu, 2015, s.112). Adalet ve Kalkınma Partisi aldığı \%34 oy oranı ile meclisteki 550 sandalyeden 367'sini kazanmıştır. AK Parti'yi iktidara getiren koalisyon daha fazla özgürlük ve demokrasi isteyen farklı toplumsal 
gruplardan oluşmaktadır. Dolayısıyla AK Parti'nin iktidara gelmesiyle beraber, siyasi ve kültürel bir reformasyon sürecine girilmiş ve laiklik ile İslam, devlet ile toplum ve siyaset ile toplum arasında yeni bir etkileşim dönemini başlamıştır. Bu yeni dönemde, AK Parti hem önceden devlet merkezli olan Batılılaşma sürecine toplumun katılma potansiyelini, hem de Türkiye'deki siyasi merkezin uzun süredir beklenen siyaseten yeniden tanımlanma ve Türkiye'yi Müslüman dünyanın geri kalanı için örnek alınacak bir liberal demokrasi haline getirme potansiyelini temsil etmiştir. Gelgelelim AK Parti'nin bu hedeflere ulaşma kabiliyeti, siyasi dönüşüm sürecinin kazananları ve kaybedenleri arasındaki süreğen iktidar mücadelesini tetiklemiş ve AK Parti 18 yıllık iktidarı sürecinde laisizm yanlısı mevcut iktidar seçkinlerinin pek çok meydan okumasıyla karşı karşıya kalmıştır (Çınar, 2008, s. 112).

AK Parti iktidarı sürecinde gerçekleştirdiği demokratik reformları İslami kökeni ile bağlantısı üzerinden ifade etmiştir (Cizre, 2008, s. 1). Bu yaklaşım Türk modernleşmeci geleneğini ve laiklik yaklaşımını belirleyen, İslam'ın "modern olmayan doğululuğu temsil ettiği" tezlerini alt üst eden yeni bir paradigmanın ilanıdır aynı zamanda. Nitekim Türkiye' de laikçi siyasi tasavvur, erken cumhuriyet döneminden başlayarak uzunca bir süre "tarihsel idealizm" ile malul olmuştur. Böyle bir idealizmle hareket eden siyasi seçkinler toplumdaki fertlerin "dine olan yakınlıkların anlayıp bunun sonuçlarını yorumlamak yerine, onlara tepeden 'aydınlanma' getirmeye çalış[mışlardır]. Bu tutum, tarihsel idealistlerin elitizmini ortaya koymaktan... başka bir işe yarama[mış]" ve bunun sonucunda da "İslamcı denen hareketin karmaşık yapısını, içinde barındırabileceği liberal ve demokratik muhalefet unsurlarını gözden kaçır[mıştır]" (Gülalp, 2018, s.85).

İşte böyle bir siyasi ve sosyal konjonktürde AK Parti Türk siyasetini uzunca bir süre tahakkümü altına almış olan bu tarihsel idealizm anlayışını büyük bir başarıyla tasfiye etmiş ve iktidarı sürecinde laik devlet geleneğinin öğretisindeki toplum tanımını değiştirerek İslami-muhafazakâr kimliği görünür kılmanın, merkezi toplumun referanslarına uygun olarak dönüştürmenin mücadelesini vermiş, çoğulcu ve yeni bir toplumsal sözleşme kurmaya yönelmiştir. AK Parti'nin, elitist-laik merkezin siyasetteki tahakkümünü k1rarak Türk siyasetinde özgürlükçü yeni bir siyasi merkez oluşturma mücadelesi demokrasi tahayyülünün bir sonucudur. Bu mücadele seçkinci siyaset açısından ise laiklik endişesini yükselten gerilimli bir atmosfer üretmiştir. Zira siyasi seçkinler laiklik aracılığıyla “Türkiye'de dinin özel alana çekilme 
projesini siyasal araçlarla tepeden aşağıya gerçekleştirmeye koyul[dukları]" için her zaman "dini ve dindarları regüle etme çabası" içinde olmuştur (Gülalp, 2018, s. 89). AK Parti'nin din alanındaki bu regülasyona demokratik yollarla müdahele etmek suretiyle Türkiye'de Müslüman kimliğe sahip çıkılarak, bambaşka alternatif bir modernleşme ve kalkınmanın mümkün olduğunu bilfiil kanıtlaması, baskıcı modernleşme söylemini tamamen hükümsüz kılmıştır.

Müslüman kimliğine sahip çıkan bu misyonuyla AK Parti'nin siyasi programı devletin kamusal kaynaklarının dağıtımının dışında bulunan İslami sermayenin güçlenmesinin önünü açmış ve alternatif finansal kaynaklarla toplumun zenginleşmesini sağlamıştır. Modernleşme sürecinden dışlanan İslami-muhafazakâr kesim, AK Parti bünyesinde süreci revize edebilecek imkâna kavuşmuştur. İslami yaşayış demokratik ve ekonomik gelişmenin itici gücü olarak konumlandırılmış ve bu alternatif modernleşmenin toplumun ara yüzlerini, seçkinci siyasetin dışladığı kesimleri de kapsayan bir kimlik formu ile zenginleşmesi sağlanmıştır (Doğanay, 2014, s. 66). AK Parti sadece İslamcı/muhafazakâr kesime alan açmakla kalmamış, aynı zamanda mütedeyyin kesimlerin siyasal ve kültürel hareket alanına sistemli olarak k1sitlama getiren merkezin kendisini dönüştürmeyi de başarmıştır. Türkiye'de modernleşmenin en temel krizini üreten dügüum noktasına nişan almak bir anlamda "arı kovanına çomak sokmak" gibidir. AK Parti uzun erimli bir mücadeleye dayanan ve pek çok siyasi riski göğüslemeyi gerektiren bu süreçte yaşanan pek çok krizi milli iradeden aldığı güç ile aşmayı başarmıştır (Doğanay, 2014, s.66).

Adalet ve Kalkınma Partisi; İslami kimliğin kamusal hayatta görünürlüğün önüne konan bütün engellerle tek tek mücadele etmiş, İslami-muhafazakâr kesimlerin gündelik yaşamını rahatlatacak pek çok uygulamayı hayata geçirmiştir. Türk modernleşmesinin toplumsal çatışma sahalarından en önemlisi şüphesiz ki kadının kamusal alandaki görünürlüğünü tanzim etmek meselesi olmuştur. Cumhuriyetin modern yüzünün temsilcisi olarak öne çıkarılan kadın aynı zamanda cumhuriyet ideolojisinin taşıyıcısı ve rehberi olarak görülmüştür (Yaralı Akkaya, 2019, s. 2436). Bu ideolojiye göre, ilerici, batıcı, modern bir görünümün temsilcisi olan kadın karanlığı, geriliği, geçmişi temsil eden türban, başörtüsü gibi "ilkel" sembollerden "kurtulmuş"tur. Dolayısıyla kamusal alan sadece dini sembollerden arınmış, mo- 
dern ve laik görüntülü kadınlara açık olacak bir şekilde, tek tipçi ve ötekileştirici bir mantıkla tasarlanmıştır. Nitekim AK Parti'nin merkezi dönüştürme hamlelerinin ürettiği çatışmanın en kesif bir şekilde görünür hale geldiği temel meselelerden birisi de kadının kamusal alandaki görünümü olmuştur. Türk kadınının yüzde 60'ından fazlasının kullandığı baş örtüsünün (Elver, 2012, s. 17) ve bu görüntü altındaki simge, değerler ve yaşam tarzının kamusal alanda ve siyasi merkezde artık demokratik yollarla temsil ediliyor oluşu, laiklik tartışmaları ekseninde uzun süren bir çatışmayı tetiklemiştir. Zira Elver' in işaret ettiği gibi, dindarlık ile modernite arasındaki netameli ilişki, Türkiye de dahil, laik addedilen çoğu toplumda Müslüman kadınlar için olumsuz sonuçlar doğurmuştur ve bunlar "ciddi insan hakları ihlallerine yol açan yasal ve toplumsal segregasyonlar şeklinde tezahür etmiştir" (Elver, 2018, s. 3). Nitekim AK Parti'nin başarısı, Türkiye'de türban meselesi üzerinden yaşanan kronik insan hakları ihlallerini ve dindar kadınların maruz kaldığı segregasyonu ortadan kaldırması ve böylece demokratik bir kamusal alanın inşasında büyük bir atılım gerçekleştirmiş olmasıdır.

AK Parti genel olarak dayatmacı laiklik modelini dönüştürmek, özelde ise başörtüsü yasağını kaldırmak için birçok girişimde bulunmuş, ancak ilk iki iktidar döneminde mevcut anlayışı değiştirmek konusunda şiddetli bir mukavemetle karşlaşmıştır (Akyüz, 2016, s.67). AK Parti kendisine müesses nizam tarafından çizilen sınırları her zorladığında, mesela başörtüsüne serbestlik getirmeye veya İmam Hatip Lisesi mezunlarının üniversiteye girişi önündeki engelleri kaldırmaya teşebbüs ettiğinde, laik devlet elitlerinin yoğun tepkisi ile karşılaşmış ve sistemin kırmızı çizgileri hatırlatılmıştır (Bekaroğlu, 2015, s.113). İlk kriz 2003 yılında yapılan 29 Ekim Cumhurbaşkanlığı resepsiyonuna AK Parti'lilerin, eşleri türban taktıkları gerekçesiyle, eşsiz davet edilmesi ile başlamıştır (Akyüz, 2016, s. 76). Laik müesses nizam ile AK Parti arasındaki gerilimin doruk yaptığı bir diğer olay da Mayıs 2007'de Abdullah Gül'ün cumhurbaşkanlığına aday gösterilmesidir. Müesses nizamın muhafızları Türkiye'nin laik ve çağdaş kimliğinin en üst düzey sembolü olan cumhurbaşkanlığı makamının İslamcı kökenli ve eşi başörtülü biri tarafından "ele geçirilmesi"ne razı olmamıştır (Bekaroğlu, 2015, s. 113). Bu süreç, TSK rahatsızlığının ve gerektiğinde müdahale etme kararlılığının en net ifadesini Genelkurmay Başkanlığı'nın resmi web sayfasında yayımladığı "e-muhtıra" ile bulmuş ve pik noktasına ulaşmıştır (Bekaroğlu, 2015, s. 114). Başörtüsünü kaldırma girişimleri AK Parti'yi kapatılmanın eşiğine getirmiş, 2008 yılında 
partiye kapatılma davası açılmıştır (Akyüz, 2016, s. 79). AK Parti devlet elitleri ile girdiği mücadelede yaşadığı mağduriyetleri, seçmenini konsolide ederek, arkasındaki toplumsal desteği arttırarak aşmıştır. 2007 ve 2011 seçimlerinde oy oranını yükseltmiş ve kurduğu tek parti hükümetleri ile sivil ve askerî bürokrasi karşısında daha fazla güç elde edebilmiştir (Bekaroğlu, 2015, s. 116). AK Parti üç dönem üst üste tek başına iktidara geldikten sonra yapılan düzenlemelerle baş örtüsü yasağını kaldırmayı başarabilmiştir. Anayasa değişikliği, kanun, kanun hükmünde kararname, genelge, yönetmelik gibi yasal düzenlemelerle ve akademi ve bürokraside yaptığı kadro değişiklikleriyle, karar alma mekanizmalarındaki hakim dışlayıcı laiklik yaklaşımını değiştirerek, değişim için gerekli zemini kurabilmiştir (Akyüz, 2016, s. 82).

Cumhuriyetin kurucu idaresinin kafasında modernleşme Batılılaşma ile aynı anlama gelmektedir. Tepeden inme modernleşme ve sekülerleşme demokratik olmayan yöntemlerle hayata geçirilmeye çalışılmıştır. Demokrasinin özünü, laikliği fanatik bir biçimde muhafaza etmek olarak gören laikçi zihniyet. süreğen bir şekilde siyasete ve topluma müdahalelerde bulunmuş ve onu kendi kodlarına uygun bir hale getirerek dizayn etmeye çalışmıştır. AK Parti, en başından beri bu yerleşik zihniyeti dönüştürmeyi ve siyaseti topluma ve toplumun değerlerine açmayı ilke olarak benimsemiştir. Nitekim Parti'ye verilen büyük desteğin ana sebeplerinden biri de budur.

Neticede AK Parti misyonunun belirlediği siyasi ve kültürel çizgiye uygun olarak, en başından beri "dinsel özgürlügün anayasal demokrasilerde en başat prensiplerden biri olduğunu" savunmuştur (Elver, 2012, s. 1). Türkiye'de çok uzun bir süre siyasi ve sosyo-kültürel yaşamı tahakkümü altına alan ve dinin kamusal alandan tasfiye edilip kişisel vicdanlara gömülecek bir inanç meselesi olduğu yolundaki çarpık düşünceyi (Parlak, 2020, s. 20) AK Parti siyasi müdahaleleri ve yasal mücadeleleri sayesinde bertaraf etmiş ve bu çarpık düşüncenin Türkiye'nin demokratik atılımına engel teşkil etmesinin zeminini ortadan kaldırmıştır.

\section{Sonuç}

Batı'nın siyasi ve kültürel bağlamının bir ürünü olan laiklik tasavvurunun başka bir kültürel ve siyasi geleneğe cebren uygulanmaya çalışılması sonucunda, Türkiye cumhuriyetin kuruluşundan başlayarak demokratik bir toplumsal yapının inşası yolunda büyük zorluklar yaşamıştır. Nitekim seçkinci 
kadroların benimsediği pozitivist söylemin güdümünde belirlenen laiklik meselesi, toplumsal gerçekliği şekillendiren bir determinizm haline gelmiş ve devlet ile toplum arasında gitgide büyüyen bir kutuplaşma yaratmıştır. Büyük ölçüde tarihsel konjonktürün dayatmasıyla hayata geçen çok partili sistem, nihayetinde gene bu laik seçkinci kadroların hegemonyası altında varlığını sürdürmeye çalışmış ve Türkiye'de demokratik bir siyasi ve kamusal yaşamın tam anlamıyla yeşermesinin önüne geçmiştir.

Ancak AK Parti'nin iktidara gelmesiyle beraber, Türkiye'de cumhuriyet elitlerinin öngördüğünden bambaşka bir modernleşme ve kalkınma alternatifinin de mümkün olduğu ortaya çıkmıştır. AK Parti, köktenci modernist yaklaşımın savunduğunun aksine, İslamiyet'i dışlamadan, Türkiye'nin tarihsel ve kültürel sürekliliklerini kesintiye uğratmadan, laiklik gibi dayatmacı siyasi tasavvurlara başvurmadan demokratik ve modern bir toplumsal yapının inşa edilebileceğini bilfiil göstermiştir.

Nitekim günümüzde pek çok sosyolog ve siyasetbilimci laikliğin modernite ve demokrasi ile birebir bağlantısının bulunmadığını ve demokratik bir sivil toplumun işleyebilmesi için laikliğin -savunulanın aksine- bir zorunluluk olmadığını öne sürmektedir. Son dönemin tarihsel sosyoloji ve sosyal antropoloji çalışmalarının ortaya koyduğu tartışmalar göz önüne alındığında, AK Parti Türkiye'nin siyasi ve sosyo-kültürel hayatında adeta kritik bir güncelleme gerçekleştirmiş ve artık arkaik addedilen pozitivist ve dayatmacı laiklik tasavvuru ve söyleminin kamusal alana ve toplumsal hayata biteviye musallat olmasının imkânını ortadan kaldırmıştır.

AK Parti, Türkiye'nin cumhuriyet seçkinlerince öngörülen tektipleştirici ve kutuplaştırıcı bir kamusal hayata ve siyasi iklime mahkûm olmadığını göstermiş ve Türkiye'de topluma, kültüre ve siyasete dair çağdaş anlayışların ve tasavvurların filizlenip gelişeceği bir toplumsal ve siyasi zemin oluşturmuştur. AK Parti'nin temelde yaptığı iş, laiklik tartışmalarına yönelik çatışmacı yaklaşımı çözmeye yönelmek olmuştur. Nitekim Arkoun'un Türkiye Cumhuriyeti'nin kuruluş süreciyle ilgili olarak sorduğu şu soru esasen Türkiye'nin yaşadığı laiklik tartışmalarının mantığını ortaya sermektedir: "Tamamen yabancı bir tarih ve kültür yoluna sokma amacı güdülerek, bir milletin semboller dağarcığından ve inanç sisteminden koparılması nereye kadar mümkün olabilir?" Aslında bu sorunun yanıtın Türkiye tarihi bizatihi vermiştir. AK Parti iktidarlarının öncülügüünde nihayetlenen süreç ile, böyle bir şeyin ilelebet süremeyeceği, toplumların fikriyatına ve maneviyatına pranga 
vurulamayacağı ve dayatmacı yapay yollarla topluma müdahale edenlerin nihayetinde kaybetmeye mahkum olacağı kanıtlanmıştır. 


\section{EXTENDED ABSTRACT}

\section{Evolution and Overview of the Concept of Laïcité in Turkey in the Context of Contemporary Critical Theories}

Nureddin Nebati

Independent Researcher

The conception of laïcité denotes the separation of religious and state institutions, as well as state's intention to enhance the freedom of conscience and religion among its citizens. In practice, however, this has not been the case, and in many instances religion has been totally excluded from public life. Laïcité is essentially a Eurocentric concept that is born out of a specific historical experience. But, as a product of the Enlightenment era, this concept has been presented as the sole modernization model universally applicable to all societies. In the last decades, however, contemporary social science theories, and particularly post-modern critical studies, have strongly criticised the concept, pointing out its limitations. Many contemporary thinkers and scholars, such as Charles Taylor, Talal Asad and Craig Calhoun, have indicated the limitations of the conception of laïcité and criticized its assertiveness in terms of exclusion of religion from public space.

France has seen the most patronising and dogmatic implementation of laïcité. Therefore, it's important to note the limitations of the problematic French conception of laïcité, because it is this specific conception that was taken as a model for modernization in Turkey. Due to this problematic approach, religion has been completely excluded from social and political spheres, and this has spawned many serious social problems in Turkey.

The modernization of the Ottoman Empire began in the Tanzimat era, culminating in the foundation of the Turkish Republic, which was characterized by the implementation of laïcité. From 1924-25 onwards, the reforms based on assertive laïcité gradually became a comprehensive project and were considered as an essential component for the construction of the society. Nevertheless, Islam was used by the modernizing elite as an instrument for creating a common bond within the society during the Turkish War of Independence. 
After the declaration of the Turkish Republic, however, this approach was abandoned by the elite, giving way to an assertive conception of laïcité that is based on positivism. Subsequently, assertive laïcité gradually transformed into a kind of self-denial, implementing certain changes that led to social traumas, such as the recitation of Ezan (call to prayer) in Turkish.

With the liberalization of political life allowing a multiparty system, Turkey went through a new phase in the implementation of laïcité. The masses, frustrated by the practices based on patronising and assertive laïcité during the single-party regime, put the Democrat Party (DP) in power. One of the main reasons behind the widespread popular support for the DP was the social trauma caused by the single-party regime, which eliminated from the public space all the representations and symbols of Islam and religious identity. On the other hand, the DP distanced itself from assertive laïcité, but never categorically rejected it. Indeed, the DP only made certain reforms to enhance the freedom of conscience and religion. Nonetheless, the DP's attitude towards religion raised doubt and served as a strong case for the legitimacy of the military intervention.

After the 1980 coup, Turkey saw a relatively enriched and relaxed civil life in which grand narratives in Turkey, in line with global developments, collapsed, and cultural, ethnic and religious identities proliferated, and various lifestyles and social strata came into contact. Such an atmosphere facilitated the representation of Islamic identity. In the 1990s, political Islam steadily gained ground and made progress towards central economic and political spheres, achieving a significant success, but eventually found itself confronted by fierce opposition. In this period, the advocates of the established order forcefully hindered the progress of the proponents of political Islam. Consequently, the army intervened in politics with the coup of 28 February, which was based on the practices of the single-party regime.

As an impediment to civil and political life in Turkey, the conception of assertive laïcité, which formed a symbiotic relationship with Turkish modernization, endured until the 2000s. The laïcité that was characteristic of the single-party era was a constricted and archaic model. Therefore, it has met with harsh criticism in contemporary social science studies. It was only at the beginning of the 2000s, with the Justice and Development Party's rise to power, that Turkey could transform the constricted and archaic world view of laïcité, extending the public and political spheres to welcome pluralities and Islamic 
identity. The Justice and Development Party's long struggle against the centre, which entailed overcoming politically risky obstacles, achieved great success with the unflinching support of the majority of society, culminating in a paradigm shift in Turkish political and public life.

\section{Kaynakça / References}

Akyüz, İ. (2016). Türkiye'de dışlayıcı laiklikten pasif laikliğe geçiş sürecinde başörtüsü yasağının kaldırılması. Turkish Studies International Periodical for the Languages, Literature and History of Turkish or Turkic, 11(7), 67-84.

Arkoun, M. (1994). İslami bir bakış açısı içinde pozitivizm ve gelenek, Kemalizm olay1. Cogito, 1, İstanbul: YKY.

Asad, T. (1993). Genealogies of religion: Discipline and reasons of power in Christianity and Islam. Baltimore: The Johns Hopkins University Press.

Asad, T. (2003). Formation of the secular: Christianity, Islam, modernity. California: Stanford University Press.

Arslan, N. (der.) (1990). Atatürk'ün söylev ve demeçleri. Cilt 1, Ankara: Türk İnkilap Tarihi Enstitüsü.

Azak, U. (2019). Türkiye'de laiklik ve İslam. İstanbul: İletişim Yayınları.

Bekaroğlu, E. A. (2015). Post-laik Türkiye?: AK Parti iktidarları ve güncellenen laiklik sözleşmesi. İnsan ve Toplum, 5(9), 102-122.

Bora, T. (2018). Cereyanlar: Türkiye'de siyasî ideolojiler. İstanbul: İletişim Yayınları.

Bölükbaşı, M. (2012). Milli Görüş'ten muhafazakâr demokrasiye: Türkiye'de 28 Şubat süreci sonrası İslami elitlerin dönüşümü. İnsan ve Toplum Bilimleri Araştırmaları Dergisi, 1(2), (166-187).

Calhoun, J. C. (2011). Secularism, citizenship, and the public sphere, rethinking secularism. New York: Oxford University Press.

Cizre, Ü. (2008). Introduction: The Justice and Development Party: Making choices, revisions and reversals interactively (Der.), Secular and Islamic Politics in Turkey: The Making of The Justice and Development Party içinde, (s. 1-14). New York and London: Routledge.

Copson, A. (2019). Secularism. Oxford: Oxford University Press Ebooks.

Çınar, M. (2008). The Justice and Development Party and the Kemalist establishment (Der.), Secular and Islamic Politics in Turkey: The Making of The Justice and Development Party içinde, (s. 109-130). New York and London: Routledge. 
Demokrat Parti (1946). Parti programı. 26 Ağustos 2020 tarihinde https://acikerisim.tbmm.gov.tr/xmlui/bitstream/handle/11543/917/200805461 1946.pdf?sequence=1\&isAllowed=y adresinden erişildi.

Doğanay, T. C. (2014). Adalet ve Kalkınma Partisi'nin muktedir iktidarı ve sistem meşrulaştırması. KMÜ Sosyal ve Ekonomik Araştırmalar Dergisi, 16(27), 6572.

Elver, H. (2012). The headscarf controversy: Secularism and freedom of religion (Religion And Global Politics). New York: Oxford University Press.

Erdoğan, R. T. (2004). Uluslararası muhafazakârlık ve demokrasi sempozyumu açılış konuşması. Uluslararası Muhafazakârlık ve Demokrasi Sempozyumu, İstanbul: AK Parti Yayınları.

Esen, B. N. (1968). Türk Anayasa Hukuku, Ankara: Ayyıldız Matbaası.

Gökmen, Ö. (2002). 28 Şubat: Bir “batılllaşma restorasyonu mu? (Der.), Modern Türkiye'de Siyasî Düşünce: Modernleşme ve Batıcılık içinde, (s. 347-350). Cilt 3, İstanbul: İletişim Yayınları.

Göle, N. (1998). Modernleşme bağlamında İslami kimlik arayışı. (Der.), Türkiye'de Modernleşme ve Ulusal Kimlik içinde, İstanbul: Tarih Vakfı Yayınları.

Gözler, K. (2008). Anayasa Hukukuna giriş. Bursa: Ekin Yayınları.

Gülalp, H. (2018). Laiklik, vatandaşlık, demokrasi: Türkiye'nin siyasal kültürü üzerine çalışmalar. İstanbul: Metis Yayınları.

Habermas, J. (2003). Kamusallı̆̆ın yapısal dönüşümü. İletişim Yayınları.

Hobsbawn, E. (2003). The age of revolution (1789-1848), Londra: Abacus.

Kadıoğlu, A. (1998a). Laiklik ve Türkiye'de liberalizmin kökenleri. Defter, 33, İstanbul: Metis Yayınları.

Kadıoğlu, A. (1998b). Republican epistemology and Islamic discourses in Turkey in the 1990s, The Muslim World, 88(1),1-21.

Kadıoğlu, A. (2010). The pathologies of Turkish republican laicism. Philosophy and Social Criticism, 36(3), 489-504.

Kalaycıoğlu, E. (2000). 1960 sonrası Türk politik hayatına bir bakış: Demokrasi neo-patrimonyalizm ve istikrar (Der.), Türkiye'de Politik Değişim ve Modernleşme içinde, (s. 387-412). İstanbul: Alfa Yayınları.

Koca, B. (2019). Ellili yıllarda merkez sağ: Demokrat Parti'nin özgürlük ile istismar arasındaki dini politikaları. (Der.), Türkiye'nin 1950'li Yılları içinde, (s. 293-31). İstanbul: İletişim Yayınlatı,

Köktaş, M. E. (1997). Din ve siyaset: Siyaset davranış ve dindarlık. Ankara: Vadi Yayınları. 
Kuru, A. T. (2009). Secularism and state policies toward religion The United States, France, and Turkey. New York: Cambridge University Press.

Locke, J. (1823). The works of John Locke, Londra: Thomas Tegg.

Merleau-Ponty, M. (1973). Adventures of the dialectic. (J. Bien, Çev.). Evanston: Northwestern University Press.

Narlı, N. (1994). Türkiye'de laikliğin konumu. Cogito, 1, İstanbul: YKY.

Parlak, D. (2020). Laikleşme sürecinde camiler. İstanbul: İletişim Yayınları.

Proast, J. (1690). The argument of the Letter concerning toleration. Londra: George West and Henry Clements.

Schneier, E. (2016). Muslim democracy: Politics, religion and society in Indonesia, Turkey and the Islamic world. New York and London: Routledge.

Taylor, C. (2018). A secular age. Cambridge: Harvard Universtiy Press.

Taylor, C. (2011). Western secularity: Rethinking secularism. New York: Oxford University Press.

TBMM Hükümet Programları ve Genel Kurul Görüşmeleri 22 Nisan 1950-20 Kasım 1961. (2013). Cilt 2, Ankara: TBMM Basımevi.

Tunahan, Ö. (2015). 28 Şubat süreci: 'Post-modern darbe'nin sosyo-politik dinamikleri ve toplum desteği. Bilgi, 30(2-3), 41.

Yaralı Akkaya, A. (2019). Türk modernleşmesinin kadın-asker sembolü Sabiha Gökçen üzerine bir değerlendirme. Opus Uluslararası Toplum Araştırmaları Dergisi, 11(18), 2433-2462.

Yavuz, M. H. (2009). Secularism and Muslim democracy in Turkey. Cambridge Middle East Studies 28. New York: Cambridge University Press.

Yeğenoğlu, M. (2007). The sacralization of secularism in Turkey, Radical Philosophy, 1(145), Londra: Radical Philosophy Group.

\section{Kaynakça Bilgisi / Citation Information}

Nebati, N. (2020). Çağdaş eleştirel kuramlar bağlamında laiklik kavramına bakış ve Türkiye'deki evrimi. OPUS-Uluslararası Toplum Araştırmaları Dergisi, 16(29), 2108-2141. DOI: 10.26466/opus.792131 